\begin{abstract}
A team of researchers, fishermen, and a netmaker in New England developed an ultra-low-opening trawl (ULOT) with a goal to reduce catches of overfished Atlantic cod (Gadus morhua) without loss of catches of other commercially important flatfish species. Use of the ULOT reduced catch rates of Atlantic cod by a mean of $48.0 \mathrm{~kg} / \mathrm{h}(46.8 \%)$ compared with the use of a standard bottom trawl. It also reduced catch rates of American plaice (Hippoglossoides platessoides) by a mean of $9.5 \mathrm{~kg} / \mathrm{h}(14.3 \%)$ but not catch rates of 3 other commercial species and 1 taxonomic group that also dominated catch. Length-based reductions in catch rates were observed, primarily for undersized American plaice $(<30.5 \mathrm{~cm}$ in total length [TL]), midrange yellowtail flounder (Limanda ferruginea) (36-38 cm TL), and large witch flounder (Glyptocephalus cynoglossus) (>40 cm TL). Mean ULOT headrope height was $0.73 \mathrm{~m}$, and $9.1 \%$ of fuel was saved. Economic evaluation indicated that the ULOT can increase profitability and fishing time by $53.7 \%$ and $88.1 \%$, respectively, confirming that it is a viable option for fishermen to avoid Atlantic cod while accessing quota of more abundant groundfish species.
\end{abstract}

Manuscript submitted 16 September 2019. Manuscript accepted 12 May 2020. Fish. Bull. 118:171-183 (2020). Online publication date: 5 June 2020. doi: 10.7755/FB.118.2.6

The views and opinions expressed or implied in this article are those of the author (or authors) and do not necessarily reflect the position of the National Marine Fisheries Service, NOAA.

\section{Development and testing of an ultra-low-opening trawl to improve utilization of quota of Atlantic cod (Gadus morhua) in the groundfish fishery of New England}

\author{
Stephen Eayrs (contact author) ${ }^{1}$ \\ Michael Pol ${ }^{2}$ \\ Jon Knight ${ }^{3}$ \\ Jim Ford ${ }^{4}$ \\ Email address for contact author: steve@gmri.org \\ ${ }^{1}$ Gulf of Maine Research Institute \\ 350 Commercial Street \\ Portland, Maine 04101 \\ ${ }^{2}$ New Bedford Office \\ Massachusetts Division of Marine Fisheries \\ 836 South Rodney French Boulevard \\ ${ }^{3}$ Superior Trawl \\ 55 State Street \\ Narragansett, Rhode Island 02882 \\ ${ }^{4}$ F/V Lisa Ann Fisheries LLC \\ 140 Willow Road \\ East Kingston, New Hampshire 03827
}

New Bedford, Massachusetts 02744
Avoiding the capture of Atlantic cod (Gadus morhua) by groundfish fishermen has become the new norm in the Gulf of Maine. This stock has declined to $4 \%$ of the target for maximum sustainable yield (NEFSC, 2015), and the commercial quota was 280 metric tons in $2017\left(\mathrm{GARFO}^{1}\right)$, a reduction of over $90 \%$ since 2013. In the fishery in the adjacent Georges Bank, the stock of Atlantic cod has suffered a similar fate, and groundfish fishermen throughout New England now frequently choose fishing locations to minimize catches of Atlantic cod to the greatest extent practicable (Eayrs et al., 2017).

Atlantic cod are caught as part of a mixed species assemblage and the imperative to avoid them in New England has previously not been strong (Eayrs et al., 2017). Many groundfish fishermen use the same bottom trawl

\footnotetext{
${ }^{1}$ GARFO (Greater Atlantic Regional Fisheries Office). 2018. FY2017 commercial annual catch limits (ACL). [Available from website.]
}

to target a mix of groundfish species that includes Atlantic cod, haddock (Melanogrammus aeglefinus), and yellowtail flounder (Limanda ferruginea) (Pol et al. ${ }^{2}$ ), often during the same tow (Rothschild et al., 2014). The vertical opening (headrope height) of these trawls is typically 1.5-3.0 m (J. Ford, personal commun.).

With quota of Atlantic cod so low, groundfish fishermen are now constrained by the risk of capturing their entire annual quota of this species in a fraction of available fishing time. The quota of Atlantic cod and other groundfish species is allocated annually to fishermen on the basis of their landing history and can be augmented by leasing or purchasing additional quota from other fishermen. However, leasing quota of Atlantic cod is problematic; quota of this species is not

\footnotetext{
${ }^{2}$ Pol, M. V., H. A. Carr, and L. R. Ribas. 2003. Groundfish trawl nets designed to reduce the catch of Atlantic cod Gadus morhua, 34 p. Mass. Div. Mar. Fish., Boston, MA. [Available from website.]
} 
always available, and leasing prices are often substantially higher than landing prices (Lee, 2017). As a result, low quota of Atlantic cod often prevents fishermen from fully using their quota of other groundfish species, and often forces them to cease fishing before the end of the fishing season.

Around the world, many modifications have been tested to improve the species selectivity of bottom trawls (for review, see Isaksen and Valdermarsen, 1994; Catchpole and Revill, 2008; Graham, 2010; Winger et al., 2010). These efforts have primarily focused on encouraging the escape of fish of non-target species once they have passed into the trawl extension piece or codend. However, fish that enter these parts of the trawl are often fatigued or exhausted (Engås, 1994; Isaksen and Valdermarsen, 1994), and fish of non-target species must overcome these stressors to reach the modification and escape, increasing their risk of injury from collision with the trawl or other fish and possible post-escape mortality (for review, see Suuronen and Erickson, 2010).

Some efforts have also been made to modify the anterior section of a bottom trawl, including modification to the upper panel or square (van Marlen, 1993; Madsen et al., 2006), the groundrope (DeAlteris et al., 1997; He and Winger, 2010; Bayse et al., 2016a), the lower panel or belly (Milliken and DeAlteris, 2004; Bayse et al., 2016b), and the sweeps and bridles (Rose et al., 2010; He et al., 2015; Sistiaga et al., 2015). They also include increased headrope length and removal of twine from the upper panel of the trawl (Thomsen, 1993; Pol et al. ${ }^{2}$; King et al., 2004; Revill et al., 2006; Chosid et al., 2008; Krag et al., 2015; Eayrs et al., 2017). Known as a topless or cutaway trawl and defined in Federal Register (2004) as a trawl with a headrope at least $30.0 \%$ longer than the footrope, this trawl relies upon the upward escape behavior of fish of non-target species as they pass over the footrope and enter the trawl mouth.

In the groundfish fishery in New England, Eayrs et al. (2017) used a topless trawl and reported a 51.4\% reduction in catch rates of Atlantic cod with no significant loss of catch of any flatfish species except American plaice (Hippoglossoides platessoides) that were undersized (below the minimum legal landing size of $30.5 \mathrm{~cm}$ in total length [TL]). The authors inferred a relationship between headrope height and layback distance (the horizontal distance between headrope and footrope at the bosom), and the position of headrope floats were key to the escape of Atlantic cod and retention of flatfish. Prior to this study, no topless trawl design had made it possible to avoid unacceptable losses of flatfish in the region (see Pol et al. ${ }^{2}$; Chosid et al. ${ }^{3}$ ), contributing to limited interest and uptake of this trawl by fishermen. Fishermen also cited the perceived revolutionary design of this trawl and concerns over headrope stability for their lack of uptake.

\footnotetext{
${ }^{3}$ Chosid, D., M. Pol, M. Szymanski, L. Ribas, and T. Moth-Poulsen. 2008. Further testing of cod-avoiding trawl net designs, $74 \mathrm{p}$. NOAA/NMFS Saltonstall-Kennedy Program completion report. Mass. Div. Mar. Fish., Boston, MA. [Available from website.]
}

Consideration had previously been given to designing a bottom trawl with a low vertical opening to avoid catching Atlantic cod. Early attempts with such a trawl were preliminarily tested in New England by Pol et al. ${ }^{2}$ but did not show any difference in catches of Atlantic cod compared with catches obtained with a standard trawl. However, results of a recent examination of video collected during that study indicate that cod swimming close to the seabed had little or no subsequent rising behavior (M. Pol, personal observ.), and it was posited that the overhanging upper panel (square) and a vertical opening less than $2 \mathrm{~m}$ were responsible for this behavior of not rising and for low escapement of Atlantic cod. On the basis of this information, we theorized that a trawl without a square and with an ultra-low vertical opening, perhaps as low as $0.6 \mathrm{~m}$ from the seabed, might be a more successful option for passing below Atlantic cod and avoiding their entry into the trawl.

Here we describe efforts to test this theory, based on testing an ultra-low-opening trawl (ULOT). We also describe the results of a second preliminary effort to test the efficacy of a modified ULOT because the results of the second study indicate improvement in ULOT performance. This modified version is increasingly being used by groundfish fishermen.

\section{Materials and methods}

The ULOT was the product of a collaborative technical committee that comprised 4 commercial groundfish fishermen, 4 fishing gear technologists, and 1 net maker. It was also the result of systematic testing and evaluation, initially done by using trawl simulation software (Dynami $\mathrm{T}^{4}$, vers. 2.1, IFREMER, Issy-les-Moulineaux, France) at the Fisheries and Marine Institute of Memorial University, Canada, and then by scale model (1:10 scale) testing in a flume tank at the Fisheries and Marine Institute. For a fuller description of the collaboration and development process, see Pol and Eayrs ${ }^{5}$.

The performance of a full-scale ULOT (Fig. 1) was then compared against that of a standard bottom trawl (Fig. 2) over a 14-d period in May and June 2016 in the Gulf of Maine (Fig. 3). Both trawls had a 2-seam design and were constructed from 152.4-mm polyethylene netting with a twine diameter $(\varnothing)$ of $3.0 \mathrm{~mm}$. The twine area of each trawl was $14.9 \mathrm{~m}^{2}$ (excluding the codend), and the fishing circle of the ULOT and the standard trawl measured 36.6 and $32.9 \mathrm{~m}$, respectively. The ULOT was designed to achieve a vertical opening of $0.6 \mathrm{~m}$. The headrope of the ULOT measured $31.3 \mathrm{~m}$, and the headrope of the standard trawl measured $24.5 \mathrm{~m}$; the headrope-to-footrope

\footnotetext{
${ }^{4}$ Mention of trade names or commercial companies is for identification purposes only and does not imply endorsement by the National Marine Fisheries Service, NOAA.

${ }^{5}$ Pol, M., and S. Eayrs. 2018. Developing an ultra-low-opening groundfish trawl to avoid cod and ensure a prosperous inshore fishing fleet, 69 p. Final report. [Available from Mass. Div. Mar. Fish., 251 Causeway St., Ste. 400, Boston, MA 02114.]
} 


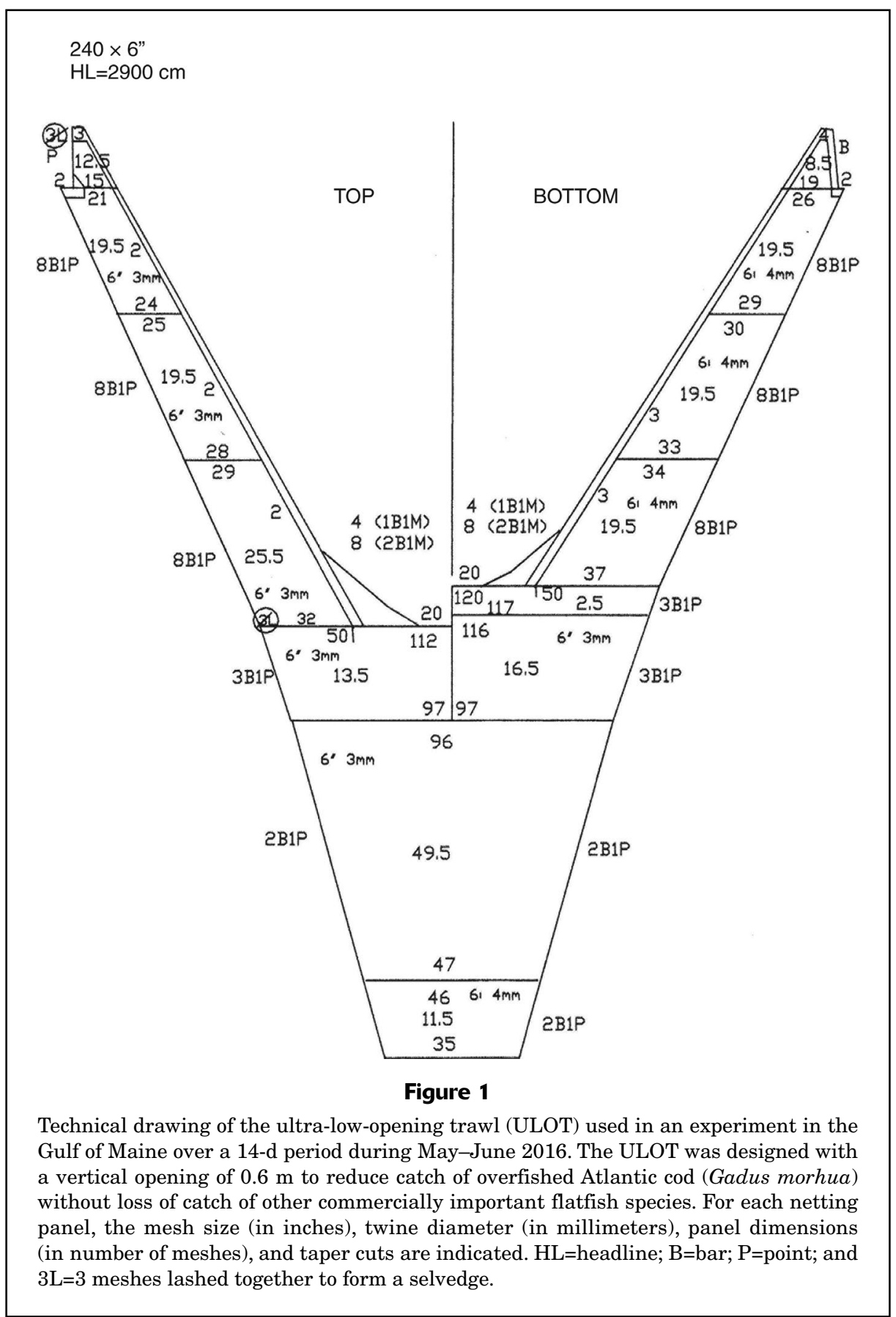

ratios were 1.08:1 and 0.84:1, respectively. Both trawls were fitted with an identical cookie sweep (ground line) that comprised a $12.7-\mathrm{mm}-\varnothing$ steel-wire rope threaded through 76.2-mm- $\varnothing$ rubber disks, and they used identical codends with 165-mm square meshes.

The headrope flotation of the ULOT comprised 8 plastic floats measuring $203 \mathrm{~mm} \emptyset ; 1$ float was attached close to each wingend, and 1 float was attached adjacent to each seam joining netting panels in the wings. There was no float in the center of the headrope. The standard trawl was fitted with 16 floats measuring $203 \mathrm{~mm} \emptyset$, as per normal commercial practice for this trawl; 2 floats were in the center of the headrope, 3 floats were spread approximately $1 \mathrm{~m}$ apart at each wingend, and the remaining floats were spread evenly between those near the wingend and those at the center of the headrope.

Both trawls were spread horizontally by using Type 14-VFA Thyborøn semipelagic otter boards (Thyborøn Skibssmedie A/S, Thyborøn, Denmark) with a surface area of $1.75 \mathrm{~m}^{2}$ and a total of weight of $440 \mathrm{~kg}$. They were also fitted with sweeps that were $82.3 \mathrm{~m}$ (45 fathoms) long and constructed from 41-mm- $\emptyset$ steel-wire rope, including 


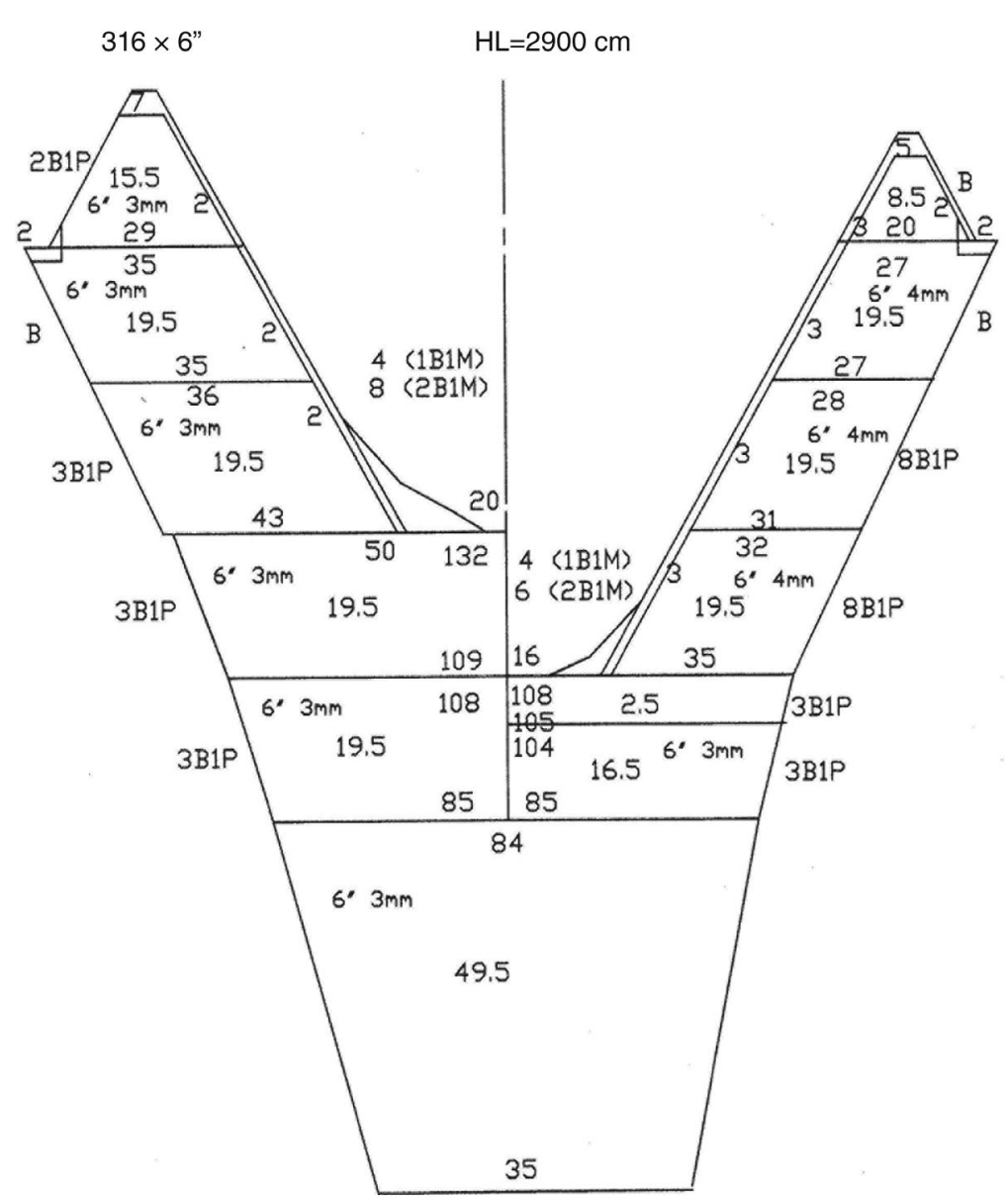

Figure 2

Technical drawing of the standard bottom trawl used in an experiment in the Gulf of Maine over a 14-d period during May-June 2016. Catches with the standard trawl and the ultra-low-opening trawl (ULOT) were compared to examine the efficacy of the ULOT at reducing catch of overfished Atlantic cod (Gadus morhua) without loss of catch of other commercially important flatfish species. For each netting panel, the mesh size (in inches), twine diameter (in millimeters), panel dimensions (in number of meshes), and taper cuts are indicated. $\mathrm{HL}=$ headline; $\mathrm{B}=\mathrm{bar}$; and $\mathrm{P}=$ point. 27.4-m (15-fathom) bridles (legs). On the last $2 \mathrm{~d}$ of field testing, the sweeps were extended by $27.4 \mathrm{~m}$, and 2 floats measuring $203 \mathrm{~mm} \emptyset$ were added to the center of the ULOT headrope.

Catch data from each trawl were collected from 3 pairs of hauls per day: 3 hauls of the ULOT and 3 hauls of the standard trawl in an A-B-B-A-A-B sequence. The trawl from the final haul was then the first trawl used the following day. Individual hauls in a haul pair were conducted in the same direction. The FV Lisa Ann III, a 16.1-m stern trawler, was used in this experiment. This vessel was equipped with a double net reel so that each trawl could be quickly deployed or stowed clear of the deck when not in use. For each haul, vessel towing speed (in meters per second), door spread (in meters), rate of fuel consumption (in liters per hour), engine revolutions (in hertz), and water depth (in meters) were recorded at 10-min intervals. The vertical opening of the ULOT was measured during 5 consecutive hauls by using pressure and depth sensors attached to the upper and lower netting panel, immediately behind the center of the headrope and footrope, respectively; these sensors were only available for $1 \mathrm{~d}$. All hauls were limited to daylight hours, between 0500 and 1430 .

The catch from each haul was sampled by species. All groundfish of regulated species were sorted by species into kept and discarded (undersized) categories prior to being weighed to the nearest $0.1 \mathrm{~kg}$. Noncommercial species were weighed prior to being discarded overboard; discarding was not permitted during towing. All catch rates (in kilograms per hour) were standardized to a haul duration of $60 \mathrm{~min}$. Total lengths of individuals of important species were measured to the nearest centimeter. Occasionally, catch of a species was excessive and necessitated collection of a subsample for lengths; the total number of individuals for each of these species at each length was then extrapolated on the basis of the proportion of the weight of the subsample to the total catch of the species.

Catch rates of regulated groundfish species and dominant species were compared graphically between trawl types and types of rigging by using equal catch plots. Paired 2-sample $t$-tests were applied to compare catch rates of Atlantic cod, American plaice, yellowtail flounder, witch flounder (Glyptocephalus cynoglossus), American lobster (Homarus americanus), and unclassified skates (Rajidae) for each haul. Results of a Welch's $t$-test were used when the results of $F$-tests for unequal variance indicated a significant difference $(P<0.05)$. For Atlantic cod, a 1 -sided $t$-test was appropriate given that the ULOT was designed to reduce the catch of this species, and a 2-sided hypothesis of equal mean catch rates was tested for the remaining species. All tests were performed separately on data collected before and after the modifications to the ULOT.

Length-based differences of Atlantic cod, American plaice, yellowtail flounder, and witch flounder were explored through the use of generalized linear mixed models (GLMMs). For each species, low-order polynomials were fitted to the proportions at length in the catch from the ULOT as a proportion of the total count at length from both trawls (Holst and Revill, 2009). Lengths with total counts greater than 5 individuals were used as a 


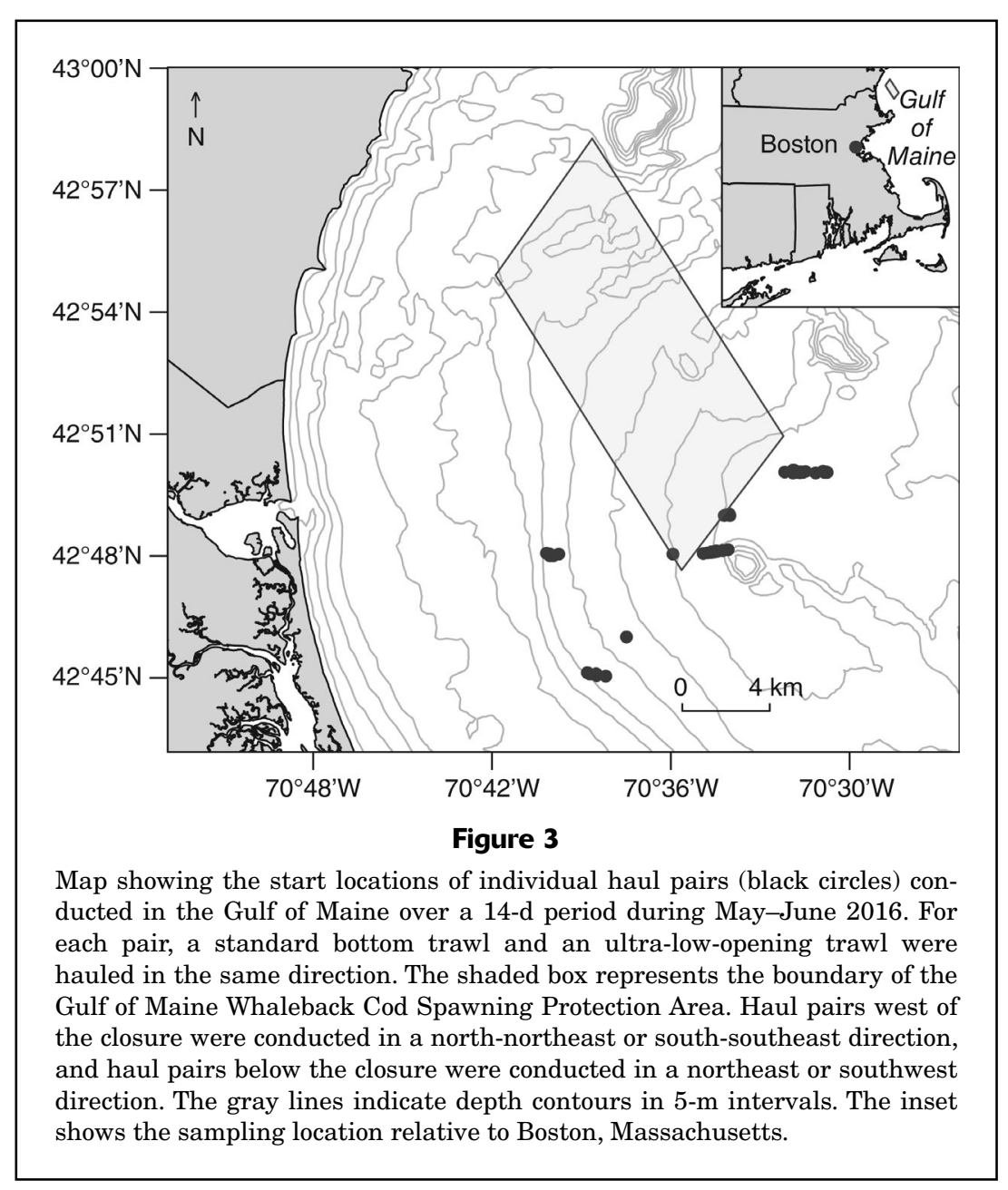

\section{Results}

Data on the fishing and engineering performance of the ULOT (original and modified) and standard bottom trawl were collected from 67 hauls, with 31 valid haul pairs over the entire sampling period. Recorded mean towing speed was $1.4 \mathrm{~m} / \mathrm{s}$ (range: $1.35-1.45 \mathrm{~m} / \mathrm{s}$ ), and mean fishing depth was $97.6 \mathrm{~m}$ (range: 54.9-116.2 m). The median interval between hauls within a haul pair was $20.0 \mathrm{~min}$, and the median length of towing (warp) wire was $299.7 \mathrm{~m}$ (range: $182.9-337.2 \mathrm{~m}$ ). The weather was calm throughout the experiment, and at no stage was wave height greater than $1.1 \mathrm{~m}$. Mean haul duration was $1.0 \mathrm{~h}$ (range: $0.97-1.1 \mathrm{~h}$ ).

The total catches in the standard trawl and ULOT were 8733.5 and $7266.8 \mathrm{~kg}$, respectively, and included fish, crabs, and lobsters from 35 taxa captured over $67.0 \mathrm{~h}$ of trawling (Table 1). Five species and 1 taxonomic group, including Atlantic cod, American plaice, yellowtail flounder, witch flounder, American lobster, and unclassified skates, accounted for $92.0 \%$ of the total catch by weight. The mean subsampling ratio for lengths per haul and species was 0.94 (range: $0.05-1.00$ ).

Use of the original ULOT reduced catch rates of Atlantic cod significantly by a mean of $48.0 \mathrm{~kg} / \mathrm{h}$ or $46.8 \%$ (Table 2). The observed $P$-value was less than 0.025 , indicating that the mean difference is

fixed effect, and haul was a random effect. In cases when subsampling occurred, an offset (intercept term) equal to the proportion of the subsample was used (ranging from 0 to 1 ) to incorporate uncertainty due to subsampling. If subsampling of lengths of both kept and discarded fish occurred for a species, the analysis was repeated, once by using the minimum of the 2 proportions and once by using the maximum, and differences (if any) were compared. A binomial distribution is appropriate to describe catches in alternating gear experiments (Wileman et al., 1996); therefore, a binomial link function was used. Following Holst and Revill (2009), we fitted a cubic polynomial model to the proportions, followed by models of decreasing complexity until all terms were significant. Model terms were assessed for differences from zero with Wald tests at $P<0.05$.

A basic economic evaluation between the 2 trawls was also completed on the basis of comparison of catch between the trawls and landings value, as determined from landing prices, fuel price, and costs of leasing quota of Atlantic cod at the time of the study. This evaluation was completed to provide greater insight into the performance of the ULOT, including its effect on fishing time and profitability. significant whether 1- or 2-tailed tests are used. Catch rates ranged up to $224.5 \mathrm{~kg} / \mathrm{h}$, and they were lower in the ULOT in 22 of the 25 haul pairs (Fig. 4). Nearly all Atlantic cod were measured (855 individuals, extrapolated to 866 individuals; a few were discarded prior to measure). They ranged in size from 45 to $109 \mathrm{~cm}$ TL; lengths with total counts greater than 5 individuals ranged from $56-89 \mathrm{~cm}$ TL. The proportion of Atlantic cod at length in the catch from the original ULOT was best described by a linear relationship without an intercept term $(P<0.00)$ (Table 3$)$. This GLMM depicts fewer Atlantic cod at all sizes in catch from the ULOT and appeared to adequately fit the pooled data, with overdispersion (i.e., observed variance greater than modeled variance) apparent at many sizes and unclear trends apparent at the rare small $(<56 \mathrm{~cm}$ TL) and large (>89 cm TL) sizes (Fig. 5).

The mean difference in catch rates of American plaice between the original ULOT and standard trawl was relatively small (10.5 kg/h, 14.3\%) but significant (Table 2). Catch rates ranged up to $132.2 \mathrm{~kg} / \mathrm{h}$ and were relatively similar in 24 haul pairs (Fig. 4), although a difference as much as $63.9 \mathrm{~kg} / \mathrm{h}$ was observed between haul pairs. American plaice ranged in size from 17 to $57 \mathrm{~cm}$ TL, with 5725 individuals measured and an expanded count 


\section{Table 1}

Composition of catch from the standard bottom trawl and the original ultra-low-opening trawl (ULOT) during May-June 2016 in the Gulf of Maine. Alternative common names for some species are given in parentheses after their recognized common names.

\begin{tabular}{llrr}
\hline & & \multicolumn{2}{c}{ Catch (kg) } \\
\cline { 2 - 4 } Species & Scientific name & Standard & ULOT \\
\hline Atlantic cod & Gadus morhua & 2830.1 & 1644.3 \\
American plaice & Hippoglossoides platessoides & 2385.9 & 2327.4 \\
Yellowtail flounder & Limanda ferruginea & 1640.1 & 1671.9 \\
Witch flounder (grey sole) & Glyptocephalus cynoglossus & 402.8 & 402.9 \\
American lobster & Homarus americanus & 370.2 & 402.9 \\
Skates & Rajidae & 357.0 & 285.4 \\
Goosefish & Lophius americanus & 275.8 & 201.8 \\
Silver hake (whiting) & Merluccius bilinearis & 110.7 & 59.5 \\
Crabs & Brachyura & 84.1 & 70.5 \\
Sea scallop & Placopecten magellanicus & 46.8 & 40.9 \\
Haddock & Melanogrammus aeglefinus & 61.9 & 25.6 \\
Spiny dogfish & Squalus acanthias & 31.4 & 50.1 \\
Fourspot flounder & Paralichthys oblongus & 38.7 & 27.7 \\
Winter flounder (blackback) & Pseudopleuronectes americanus & 24.6 & 23.9 \\
Atlantic halibut & Hippoglossus hippoglossus & 32.0 & 0.0 \\
Lumpfish & Cyclopterus lumpus & 11.2 & 15.2 \\
Red hake (ling) & Urophycis chuss & 6.3 & 4.1 \\
Windowpane (sand dab) & Scophthalmus aquosus & 3.8 & 6.4 \\
Sculpin & Cottidae & 4.6 & 2.3 \\
Atlantic wolffish & Anarhichas lupus & 4.8 & 1.7 \\
Other & & 11.0 & 2.1 \\
Total & & & 7266.8 \\
& & & \\
\hline
\end{tabular}

\section{Table 2}

Comparison of catch rates of dominant species for the original and modified ultra-low-opening trawl (ULOT) and a standard bottom trawl in the Gulf of Maine during May-June 2016. The difference in catch rate, degrees of freedom, $t$-statistic, and $P$-value are also provided for each species.

\begin{tabular}{|c|c|c|c|c|c|c|c|c|c|c|c|c|}
\hline \multirow[b]{3}{*}{ Species } & \multicolumn{6}{|c|}{ ULOT (original) } & \multicolumn{6}{|c|}{ ULOT (modified) } \\
\hline & \multicolumn{2}{|c|}{ Catch rate $(\mathrm{kg} / \mathrm{h})$} & \multirow{2}{*}{$\begin{array}{c}\text { Difference } \\
(\%)\end{array}$} & \multirow[b]{2}{*}{$\mathrm{df}$} & \multirow[b]{2}{*}{$t$} & \multirow[b]{2}{*}{$P$-value } & \multicolumn{2}{|c|}{ Catch rate $(\mathrm{kg} / \mathrm{h})$} & \multirow{2}{*}{$\begin{array}{l}\text { Difference } \\
(\%)\end{array}$} & \multirow[b]{2}{*}{$\mathrm{df}$} & \multirow[b]{2}{*}{$t$} & \multirow[b]{2}{*}{$P$-value } \\
\hline & Standard & ULOT & & & & & Standard & ULOT & & & & \\
\hline Atlantic cod & 102.5 & 54.5 & 46.8 & 23 & 4.52 & 0.000 & 61.8 & 40.3 & 34.8 & 5 & 2.10 & 0.180 \\
\hline American plaice & 73.5 & 63.0 & 14.3 & 24 & 2.17 & 0.040 & 81.9 & 98.5 & -20.1 & 5 & -1.97 & 0.107 \\
\hline Yellowtail flounder & 39.9 & 39.3 & 1.3 & 24 & 0.20 & 0.843 & 66.3 & 87.6 & -32.2 & 5 & -2.07 & 0.094 \\
\hline Witch flounder & 10.3 & 9.5 & 8.3 & 24 & 1.17 & 0.253 & 16.8 & 21.8 & -29.3 & 5 & -2.80 & 0.038 \\
\hline American lobster & 11.7 & 11.7 & 0.0 & 24 & 0.00 & 0.999 & 14.1 & 12.4 & 11.8 & 5 & 0.52 & 0.625 \\
\hline Skates & 10.4 & 8.3 & 19.6 & 23 & 1.49 & 0.150 & 10.8 & 12.4 & -15.5 & 5 & -0.77 & 0.476 \\
\hline
\end{tabular}

of 8005. Adequate lengths from data to fit a GLMM for length was judged to be 19-55 cm TL (Fig. 5). The best fit model was a second order curve, with the proportion of catch in the ULOT differing from the catch in the standard bottom trawl at small sizes ( $<30.5 \mathrm{~cm}$ TL) (Table 3$)$. The model appeared to be a very good fit to the observed data, and there was some indication of greater reduction at the small sizes.
The catch rate for yellowtail flounder was slightly higher in the standard bottom trawl $(0.6 \mathrm{~kg} / \mathrm{h}, 1.3 \%)$ than in the ULOT but was not significantly different between trawls (Table 2). Catches in haul pairs were relatively similar for yellowtail flounder between trawls, and clusters of higher (up to $232.1 \mathrm{~kg} / \mathrm{h}$ ) and lower $(2.5-20 \mathrm{~kg} / \mathrm{h}$ ) catch rates were observed. Greater variation was seen at lower catch rates (Fig. 4). Lengths of yellowtail flounder 

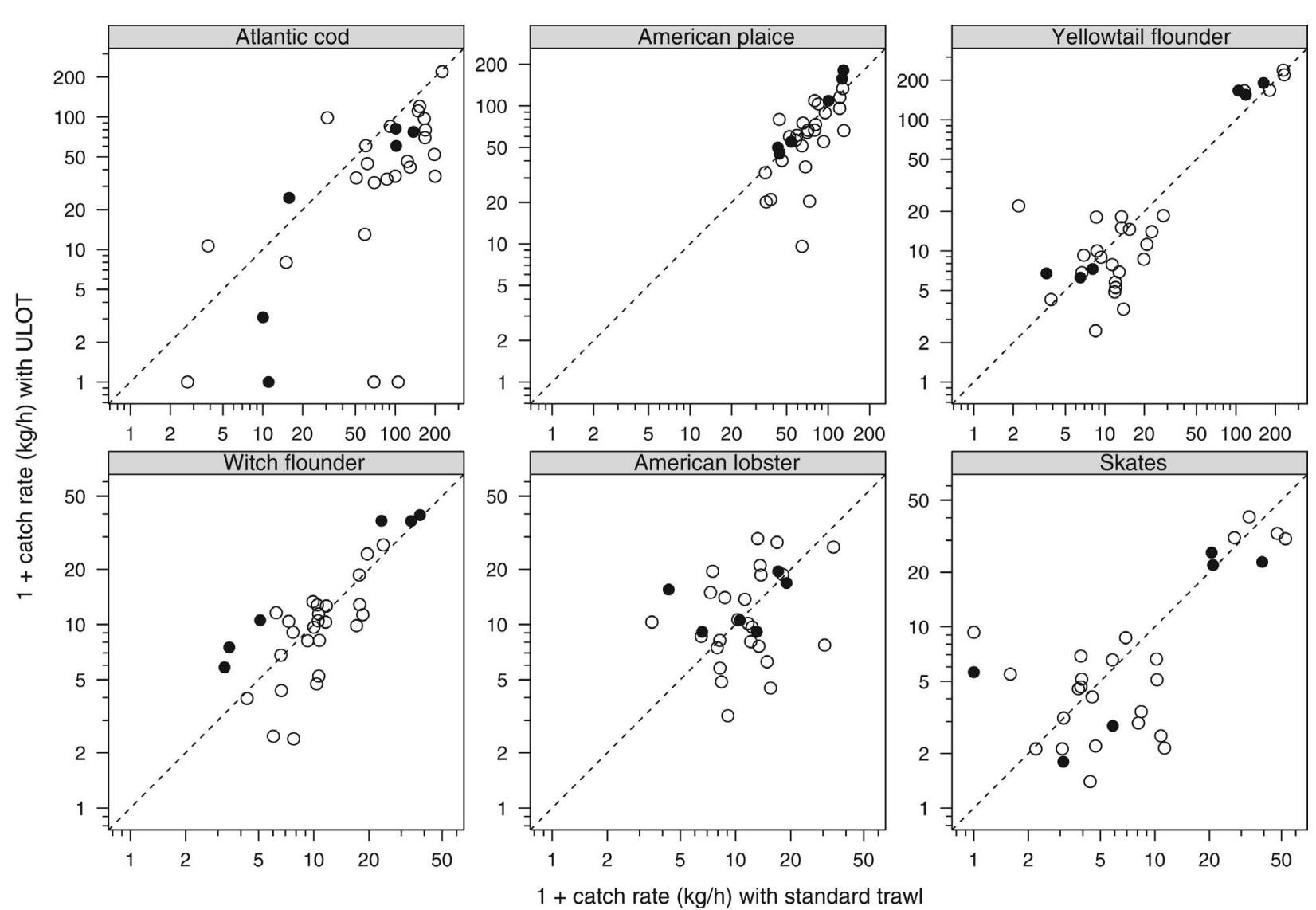

Figure 4

Plots comparing catch rates for Atlantic cod (Gadus morhua), American plaice (Hippoglossoides platessoides), yellowtail flounder (Limanda ferruginea), witch flounder (Glyptocephalus cynoglossus), American lobster (Homarus americanus), and skates (Rajidae) between an ultra-low-opening trawl (ULOT) and a standard bottom trawl over a 14-d period during May-June 2016 in the Gulf of Maine. All circles represent haul pairs, each of which consists of hauls of a ULOT and a standard trawl. Black circles represent haul pairs following a gear modification of the ULOT during the final $2 \mathrm{~d}$ of testing. The dashed diagonal line indicates the 1:1 relationship and separates haul pairs in which the catch rate was higher in the ULOT than in the standard trawl (above the line) from haul pairs in which the catch rate was lower in the ULOT than in the standard trawl (below the line).

\section{Table 3}

Mean estimates and standard errors of the mean for the parameters of the generalized linear mixed models used to analyze proportions at length of 4 dominant species in the catch from testing of the original ultra-low-opening trawl in the Gulf of Maine over a 14-d period during May-June 2016.

\begin{tabular}{llrrr}
\hline Species & Model & Parameter & Estimate & Standard error \\
\hline Atlantic cod & Linear & $\beta_{1}$ & -0.010 & 0.0022 \\
American plaice & Quadratic & $\beta_{0}$ & -3.605 & 0.6799 \\
& & $\beta_{1}$ & 0.174 & 0.0380 \\
Yellowtail flounder & Cubic & $\beta_{2}$ & -0.002 & 0.0005 \\
& & $\beta_{0}$ & -61.902 & 19.9732 \\
& & $\beta_{1}$ & 5.633 & 1.8091 \\
Witch flounder & Linear & $\beta_{2}$ & -0.169 & 0.0542 \\
& & $\beta_{3}$ & 0.002 & 0.0005 \\
& & $\beta_{0}$ & 0.953 & 0.5434 \\
& & $\beta_{1}$ & -0.028 & 0.0138
\end{tabular}



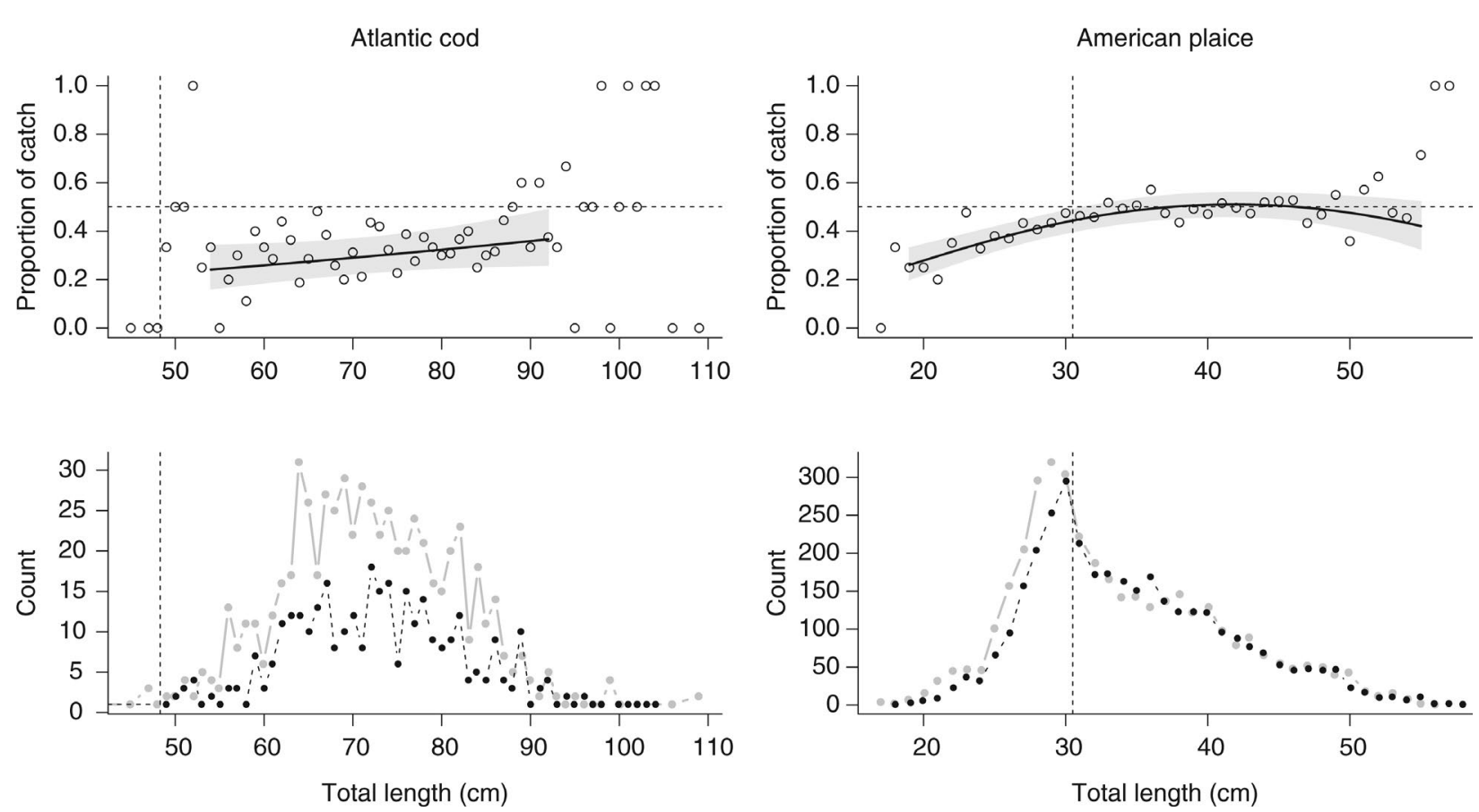

Figure 5

Proportions (top graphs) and counts (bottom graphs) at measured total lengths (TLs) of Atlantic cod (Gadus morhua) and American plaice (Hippoglossoides platessoides) retained in the catch from the original ultra-low-opening trawl (ULOT) and the standard bottom trawl during May-June 2016 in the Gulf of Maine. Estimates from generalized linear mixed models (GLMMs) and observed values are included. In the top graphs, the solid black line indicates the result of the GLMM model fit with the $95 \%$ confidence interval indicated by the gray region. The circles indicate the observed count at each length of fish caught in the ULOT as a proportion of the total count at each length from both trawls. The horizontal dashed lines indicate equal proportions in the catch from both trawls (0.5). In the bottom graphs, the dots indicate counts at total lengths in catches of the original ULOT (black dots) and the standard bottom trawl (gray dots). Vertical dashed lines represent the minimum legal landing size of Atlantic cod (48.3 cm TL) and American plaice (30.5 cm TL).

(number measured: 2676; expanded count: 6069) ranged overall from 20 to $47 \mathrm{~cm}$ TL in 24 haul pairs, and weak data at the extremes $(<24 \mathrm{~cm} \mathrm{TL}$ and $>44 \mathrm{~cm} \mathrm{TL})$ were excluded from analysis. The GLMM modeling resulted in a third-order polynomial as the model that best fit the data, indicating a significant loss of mid-sized (36-38 cm TL) yellowtail flounder (Table 3, Fig. 6). The observed proportions aligned closely with the selected model. Under this model, the estimated total reduction in catch of yellowtail flounder was $8.4 \%$ for fish $36-38 \mathrm{~cm} \mathrm{TL}$, or $2.6 \%$ of all legal-sized yellowtail flounder ( $\geq 30.5 \mathrm{~cm} \mathrm{TL})$.

Catch rates of witch flounder were slightly lower in the ULOT $(0.8 \mathrm{~kg} / \mathrm{h}, 8.3 \%)$ than in the standard bottom trawl and were not significantly different between trawls (Table 2, Fig. 4). Lengths ranged from 20 to $54 \mathrm{~cm}$ TL in 24 haul pairs (number measured: 1199; expanded count: 1239), and despite some overdispersion, a linear model provided the best fit (Table 3, Fig. 6). A small but significant loss of large ( $>40 \mathrm{~cm}$ TL) witch flounder in the catch with the ULOT was observed with a possible greater loss at the largest sizes. The estimated total reduction in catch of witch flounder was $15.8 \%$ for fish $>40 \mathrm{~cm} \mathrm{TL}$, or $4.3 \%$ of all legal-sized witch flounder ( $\geq 33.0 \mathrm{~cm} \mathrm{TL})$.

Catch rates of American lobster were identical between trawls (Table 2). They were not measured for length. A mean loss of $2.1 \mathrm{~kg} / \mathrm{h}(19.6 \%)$ was observed in the catch of skates with the ULOT but was not significantly different from the loss observed in catch with the standard trawl (Table 2). Lengths were also not collected for skates.

The mean catch rate of all 5 species and the unclassified skates with the modified ULOT ( 6 haul pairs) was not significantly different to the mean catch with the standard trawl, with the exception of a significant increase in the catch rate for witch flounder (Table 2). In this small sample, use of the modified ULOT reduced catches of Atlantic cod by a mean of $34.8 \%$ and increased catch rates for all 3 flatfish species by $20.1-32.2 \%$. There was no significant difference in catches of American lobster and skates between trawls.

For every haul pair, door spread (measured in meters) was wider during the ULOT haul than during the haul of the standard trawl (Fig. 7). Overall, with the original 

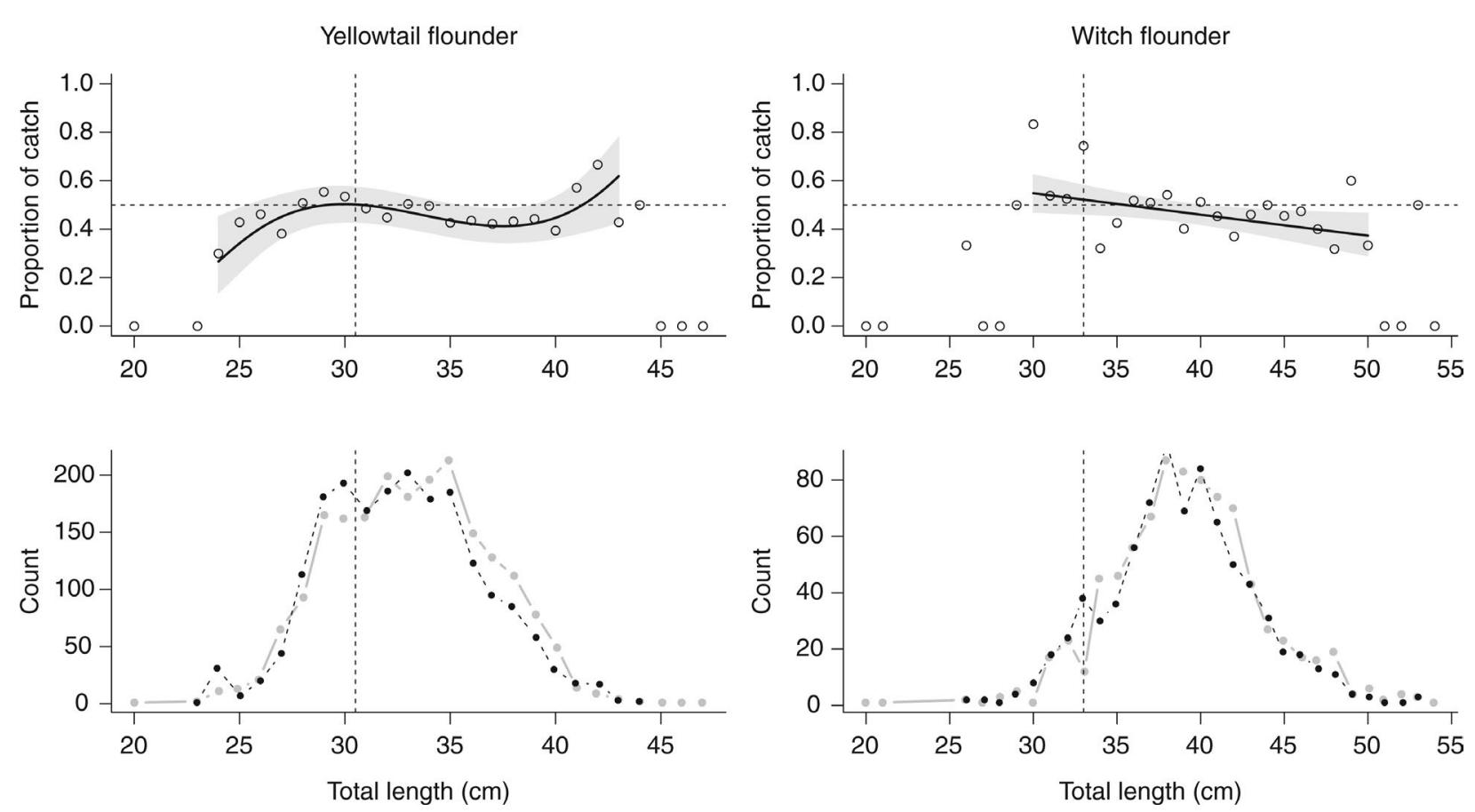

Figure 6

Proportions (top graphs) and counts (bottom graphs) at measured total lengths (TLs) of yellowtail flounder (Limanda ferruginea) and witch flounder (Glyptocephalus cynoglossus) retained in the catch from the original ultra-low-opening trawl (ULOT) and the standard bottom trawl during May-June 2016 in the Gulf of Maine. Estimates from generalized linear mixed models (GLMMs) and observed values are included. In the top graphs, the solid black line indicates the result of the GLMM model fit with the $95 \%$ confidence interval indicated by the gray region. The circles indicate the observed count at each length of fish caught in the ULOT as a proportion of the observed total count from both trawls. The horizontal dashed lines indicate equal proportions in the catch from both trawls (0.5). In the bottom graphs, the dots indicate counts at total lengths in catches of the original ULOT (black dots) and the standard bottom trawl (gray dots). Vertical dashed lines represent the minimum legal landing size of yellowtail flounder $(30.5 \mathrm{~cm} \mathrm{TL})$ and witch flounder $(33.0 \mathrm{~cm} \mathrm{TL})$.

ULOT, the door spread increased by a highly significant $6.5 \mathrm{~m}(10.7 \%)$ compared with the spread of the standard trawl (Table 4). Engine revolutions were lower with this trawl by $0.7 \mathrm{~Hz}(2.7 \%)$, and fuel consumption was significantly reduced by $2.4 \mathrm{~L} / \mathrm{h}(6.5 \%)$. The mean door spread of the modified ULOT increased significantly to $17.2 \mathrm{~m}$ from that of the standard trawl, and there was no significant difference in engine revolutions or fuel consumption.

The mean vertical opening of the original ULOT was $0.73 \mathrm{~m}$ (standard deviation 0.049), and headrope height was an estimated $0.81 \mathrm{~m}$ when the $\emptyset$ of the ground rope was considered. The crew considered the original and modified ULOT to be no more difficult to use on board than the standard trawl.

A 46.8\% reduction in the catch rate of Atlantic cod with the use of the original ULOT means that fishermen can increase fishing time for other species by $88.1 \%$ before exhausting their quota of Atlantic cod. This means they can conceivably utilize their quota of other groundfish species more fully and increase total landings value by $34.9 \%$ after additional fuel costs are considered (Table 5).
If the entire catch of Atlantic cod is landed by using leased cod quota, and the additional fishing time is fully utilized, total landings value is increased to almost $53.7 \%$ with the ULOT.

With the modified ULOT, fishing time can increase by only $53.4 \%$ before quota of Atlantic cod is exhausted because this modification was less effective in reducing the cod catch. If the full quota of Atlantic cod is utilized, landings value will increase by $56.7 \%$ because this trawl retained a higher proportion of flatfish than the original ULOT. This percentage is increased to $73.2 \%$ if the catch of Atlantic cod is landed by using leased quota of Atlantic cod.

\section{Discussion}

The ULOT represents the first known successful attempt to reduce headrope height to avoid Atlantic cod and retain flatfish in New England. Catches of Atlantic cod were reduced by nearly $47 \%$ by using the original ULOT, and there was no significant difference in catch of yellowtail 

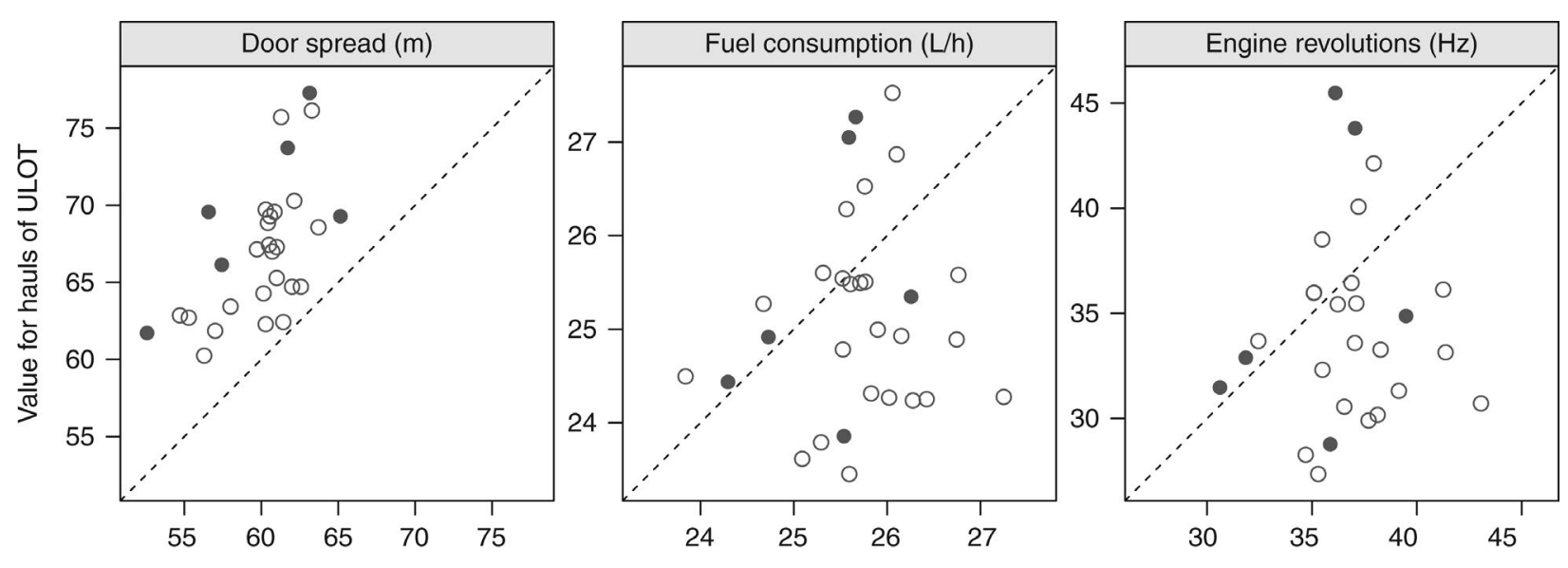

Value for hauls of standard bottom trawl

Figure 7

Plots comparing values of door spread, fuel consumption, and engine revolutions between hauls of an ultra-low-opening trawl (ULOT) and hauls of a standard bottom trawl conducted over a 14-d period during May-June 2016 in the Gulf of Maine. All circles represent haul pairs, each of which consists of hauls of a ULOT and a standard trawl. Black circles represent haul pairs following a gear modification of the ULOT during the final $2 \mathrm{~d}$ of testing. The dashed diagonal line indicates the 1:1 relationship and separates haul pairs in which the measured value was higher in the ULOT trawl than in the standard trawl (above the line) from haul pairs in which the measured value was lower in the ULOT than in the standard trawl (below the line).

\begin{tabular}{|c|c|c|c|c|c|c|c|c|c|c|c|c|}
\hline \multicolumn{13}{|c|}{ Table 4} \\
\hline \multicolumn{13}{|c|}{$\begin{array}{l}\text { Engineering performance-door spread, engine revolutions, and fuel consumption-of the original and modified ultra-low-opening } \\
\text { trawl (ULOT) compared with that of the standard bottom trawl in the Gulf of Maine during May-June } 2016 \text {. The percent difference } \\
\text { between the standard trawl and each ULOT, degrees of freedom, } t \text {-statistic, and } P \text {-value are provided for each aspect of performance. }\end{array}$} \\
\hline \multirow[b]{2}{*}{$\begin{array}{l}\text { Engineering } \\
\text { performance }\end{array}$} & \multicolumn{6}{|c|}{ ULOT (original) } & \multicolumn{6}{|c|}{ ULOT (modified) } \\
\hline & Standard & ULOT & $\begin{array}{c}\text { Difference } \\
(\%)\end{array}$ & df & $t$ & $P$-value & Standard & ULOT & $\begin{array}{c}\text { Difference } \\
(\%)\end{array}$ & $\mathrm{df}$ & $t$ & $P$-value \\
\hline Door spread (m) & 60.1 & 66.6 & -10.74 & 22 & -9.382 & 0.0000 & 59.4 & 69.6 & -17.15 & 5 & -6.837 & 0.0005 \\
\hline Engine revolutions $(\mathrm{Hz})$ & 25.8 & 25.1 & 2.72 & 23 & 2.868 & 0.0029 & 25.3 & 25.5 & -0.53 & 5 & -0.254 & 0.4048 \\
\hline Fuel consumption $(\mathrm{L} / \mathrm{h})$ & 37.2 & 33.8 & 9.12 & 20 & 3.385 & 0.0087 & 35.2 & 36.2 & -2.99 & 5 & -0.406 & 0.3506 \\
\hline
\end{tabular}

flounder or witch flounder between the original ULOT and the standard bottom trawl. Losses of American plaice were significant but limited to undersized individuals. Some loss of yellowtail flounder $36-38 \mathrm{~cm}$ TL and witch flounder $>40 \mathrm{~cm}$ TL was documented, but this reduction represented a small decrease of $<5 \%$ of landable individuals of those species. It is possible that these individuals responded to the approaching trawl by swimming over the headrope. A loss of small American plaice $(<21 \mathrm{~cm} \mathrm{TL})$ in the same fishery was also reported by Eayrs et al. (2017) during the testing of a topless trawl, and although the similar results are intriguing, they do not offer much insight into the reasons for this reduction, which remain unknown. The headline height of the original ULOT was slightly larger than desired, and a substantial reduction in fuel consumption was realized. Catches were considered typical of the commercial fishery by species, composition, and volume.

Notwithstanding a low number of haul pairs, the performance of the modified ULOT is also encouraging. Reducing the catch of Atlantic cod by almost $35 \%$ while retaining more flatfish is an improvement over the standard trawl, and we feel the efficacy of the modified ULOT should be subject to detailed evaluation in the future. This version of the ULOT has been used by several groundfish fishermen.

The original ULOT was designed to provide an effective, low-opening alternative to the multispecies groundfish trawls used in New England. Along with the topless trawl, recently evaluated by Eayrs et al. (2017) in the same 


\section{Table 5}

Comparison of total catch value for 5 dominant species in the Gulf of Maine between the standard bottom trawl and the original ultra-low-opening trawl (ULOT), based on an assumed 2000-kg quota of Atlantic cod (Gadus morhua) and landing prices during May-June 2016. Landings of other species are prorated on the basis of hourly catch rates of kept individuals during the study (see Table 2). Fuel costs for both trawl types are based on the estimated time to land $2000 \mathrm{~kg}$ of Atlantic cod by using each trawl, an assumed $8 \mathrm{~h}$ of towing time per day, and hourly fuel consumption rate. Daily fuel consumption steaming to and from the fishing grounds was typically $190 \mathrm{~L} / \mathrm{d}$ (J. Ford, personal commun.). The price of diesel fuel at the time of study was $\$ 0.63 / \mathrm{L}$. Average leased cost for Atlantic cod in 2016 was $\$ 6.05 / \mathrm{kg}$.

\begin{tabular}{|c|c|c|c|c|c|c|}
\hline \multirow[b]{2}{*}{ Species } & \multicolumn{2}{|c|}{ Catch (kg) } & \multirow{2}{*}{$\begin{array}{c}\text { Landing } \\
\text { price } \\
(\$ / \mathrm{kg})\end{array}$} & \multicolumn{3}{|c|}{ Catch value (\$) } \\
\hline & Standard & ULOT & & Standard & ULOT & $\begin{array}{c}\text { Difference } \\
(\%)\end{array}$ \\
\hline Atlantic cod & 2000.00 & 2000.00 & 8.80 & $17,600.00$ & $17,600.00$ & 0.0 \\
\hline American plaice & 1434.15 & 2313.27 & 6.60 & 9465.39 & $15,267.58$ & 61.3 \\
\hline Yellowtail flounder & 778.54 & 1442.20 & 3.96 & 3083.02 & 5711.11 & 85.2 \\
\hline Witch flounder & 200.98 & 348.62 & 11.00 & 2210.78 & 3834.82 & 73.5 \\
\hline American lobster & 228.29 & 429.36 & 13.20 & 3013.43 & 5667.55 & 88.1 \\
\hline \multicolumn{4}{|l|}{ Total catch value } & $35,372.61$ & $48,081.07$ & 35.9 \\
\hline \multicolumn{4}{|c|}{ Total catch value - fuel cost } & $34,624.68$ & $46,730.24$ & 34.9 \\
\hline \multicolumn{4}{|c|}{ Total catch value - fuel and cod lease costs } & $22,524.68$ & $34,630.24$ & 53.7 \\
\hline
\end{tabular}

fishery, this trawl improves utilization of quota of Atlantic cod; both trawls reduce catch rates of Atlantic cod and therefore extend fishing time before exhausting the quota of this species. In contrast to the topless trawl, which permits herding of Atlantic cod and entry into the trawl prior to escape over the headrope, the ULOT is designed primarily to pass below Atlantic cod and eliminate stress and physical injury during passage through the trawl. The ULOT also represents a less revolutionary trawl design that may be more easily adopted and accepted by fishermen. Trawls with approximately equal headrope and footrope lengths are used to pursue and capture other species in the region; therefore, the design is familiar to many fishermen. However, application of a ULOT-type design for avoidance of Atlantic cod with a very low opening was unknown prior to this work.

Use of the original ULOT provides an opportunity for fishermen to increase efficiency and profitability, compared with that achieved with the standard trawl, in the short term through reduced rate of fuel consumption. Using this trawl in the long term, fishermen can conceivably increase fishing time by $88.1 \%$ before exhausting their quota of Atlantic cod, and provided this time is available, 3 additional benefits can potentially be realized.

First, use of this trawl permits greater utilization of quota of other groundfish species. Based on data in NOAA reports for the fishing years $2011-2018\left(\mathrm{GARFO}^{6}\right)$, annual landings of American plaice, witch flounder, yellowtail

\footnotetext{
${ }^{6}$ GARFO (Greater Atlantic Regional Fisheries Office). 20122019. (FY2011-FY2018) commercial annual catch limits (ACL). [Available from website.]
}

flounder, and winter flounder (Pseudopleuronectes americanus) in the Gulf of Maine have respectively averaged only $80.6 \%, 86.1 \%, 73.1 \%$, and $27.3 \%$ of the annual catch limits for these species, and the ULOT provides an opportunity to increase these percentages. Second, use of the original ULOT reduces the need for fishermen to lease expensive quota of Atlantic cod, or to spend time searching for available cod quota, prior to the end of the fishing year. Finally, by fishing longer and more fully utilizing their quota of other groundfish species, fishermen can potentially increase total landings value by almost $54 \%$ after fuel costs are considered. Collectively, these benefits are a substantial incentive for fishermen to adopt the ULOT, notwithstanding the exclusion in this analysis of other operating costs, such as crew payments, food, and ice, which are more or less a constant proportion of operating costs irrespective of fishing time. The incentive to use this trawl is even more compelling when the variable cost and availability of leasing quota of Atlantic cod are taken into account, and the amortization period on the purchase of a ULOT is substantially less than that for a standard trawl, given that the cost to construct both trawls is similar (J. Knight, personal commun.).

It was our goal to develop a practical design that would lead to voluntary adoption of the ULOT by local fishermen. Outreach efforts are currently underway, including offering free use of 3 different sizes of the ULOT, and fishermen have already taken this opportunity and given positive feedback. This opportunity has been broadcast through a variety of means, including social media, printed announcements, and trade publications. Voluntary adoption of new fishing designs has been historically problematic (Eayrs 
and Pol, 2019); however, with the anticipated savings and earnings potential, we hope fishermen will readily adopt this trawl. Although not all fishermen have the capacity to increase their fishing time by $88.1 \%$ and some switch between different fisheries during the year, many fishermen are hampered in their ability to fish an entire season because of inadequate quota of Atlantic cod. Subsequently, many fishermen do have the available days to absorb some or all of this increase and realize the benefits of the ULOT. It is also worth noting that the fishermen involved in this study still use the modified ULOT.

The ULOT design is the second bottom trawl recently developed and tested in the region that has reduced catches of Atlantic cod by about half with minimal effect on catches of targeted flatfish species. These results indicate that Atlantic cod can generally be expected to swim above or rise at least $0.5 \mathrm{~m}$ in response to an approaching trawl, although we recognize that this behavior is inferred rather than directly observed. On the basis of the development of the ULOT and the topless trawl, we have established a baseline in avoidance of Atlantic cod through modification in the anterior end of a trawl and provided evidence that removal of the square has limited effect on flatfish catches. It remains unclear if further improvement in this part of the trawl is achievable, although greater reduction of bycatch of Atlantic cod is likely if these designs are paired with modifications to the extension piece or codend, such as square-mesh windows or codends.

\section{Acknowledgments}

This study was funded by the NOAA Saltonstall-Kennedy Grant Program (fiscal year 2015, grant no. NOAA-NMFSFHQ-2015-2004246). M. Pol was additionally supported by the National Marine Fisheries Service Interjurisdictional Fisheries Management Program. We would like to thank Captains T. Testaverde Sr. (FV Midnight Sun), D. Murphy (FV Bantry Bay), and C. Bouchard (FV Stormy Weather, retired) and C. Glass (University of New Hampshire) and P. He (University of Massachusetts Dartmouth) for their contribution to the development of the ULOT.

\section{Literature cited}

Bayse, S. M., C. B. Rillahan, N. F. Jones, V. Balzano, and P. He. 2016a. Evaluating a large-mesh belly window to reduce bycatch in silver hake (Merluccius bilinearis) trawls. Fish. Res. 174:1-9. Crossref

Bayse, S. M., M. V. Pol, and P. He.

2016b. Fish and squid behaviour at the mouth of a drop-chain trawl: factors contributing to capture or escape. ICES J. Mar. Sci. 73:1545-1556. Crossref

Catchpole, T. L., and A. S. Revill. 2008. Gear technology in Nephrops trawl fisheries. Rev. Fish Biol. Fish. 18:17-31. Crossref

Chosid, D. M., M. Pol, M. Szymanski, L. Ribas, and T. Moth-Poulsen. 2008. Diel variation within the species selective "topless" net. J. Ocean Technol. 3(2):31-58.
DeAlteris, J., H. Milliken, and D. Morse.

1997. Bycatch reduction in the Northwest Atlantic small-mesh bottom-trawl fishery for silver hake (Merluccius bilinearis). In Developing and sustaining world fisheries resources: the state of science and management (D. A. Hancock, D. C. Smith, A. Grant, and J. P. Beumer, eds.), p. 568-573. CSIRO Publ., Collingwood, Australia.

Eayrs, S., and M. Pol.

2019. The myth of voluntary uptake of proven fishing gear: investigations into the challenges inspiring change in fisheries. ICES J. Mar. Sci. 76:392-401. Crossref

Eayrs, S., M. Pol, S. T. Caparossi, and C. Bouchard.

2017. Avoidance of Atlantic cod (Gadus morhua) with a topless trawl in the New England groundfish fishery. Fish. Res. 185:145-152. Crossref

Engås, A.

1994. The effects of trawl performance and fish behaviour on the catching efficiency of demersal sampling trawls. In Marine fish behaviour in capture and abundance estimation (A. Fernö and S. Olsen, eds.), p. 45-68. Fishing News Books, Oxford, UK.

Federal Register.

2004. Magnuson-Stevens Fishery Conservation and Management Act provisions; fisheries of the northeastern United States; Northeast (NE) multispecies fishery; Amendment 13; correction. Fed. Regist. 69:23667. [Available from website.]

Graham, N.

2010. Technical measures to reduce bycatch and discards in trawl fisheries. In Behavior of marine fishes: capture processes and conservation challenges (P. He, ed.), p. 239-264. Wiley-Blackwell, Ames, IA.

He, P., and P. D. Winger.

2010. Effect of trawling on the seabed and mitigation measures to reduce impact. In Behavior of marine fishes: capture processes and conservation challenges (P. He, ed.), p. 295-314. Wiley-Blackwell, Ames, IA.

He, P., C. Rillahan, and V. Balzano.

2015. Reduced herding of flounders by floating bridles: application in Gulf of Maine northern shrimp trawls to reduce bycatch. ICES J. Mar. Sci. 72:1514-1524. Crossref

Holst, R., and A. Revill.

2009. A simple statistical method for catch comparison studies. Fish. Res. 95:254-259. Crossref

Isaksen, B., and J. W. Valdermarsen.

1994. Bycatch reduction in trawls by ulitizing behaviour differences. In Marine fish behaviour in capture and abundance estimation (A. Fernö and S. Olsen, eds.), p. 69-83. Fishing News Books, Oxford, UK.

King, S. E., R. W. Hannah, S. J. Parker, K. M. Matteson, and S. A. Berkeley.

2004. Protecting rockfish through gear design: development of a selective flatfish trawl for the U.S. west coast bottom trawl fishery. Can. J. Fish. Aquat. Sci. 61:487-496. Crossref

Krag, L. A., B. Herrmann, J. D. Karlsen, and B. Mieske.

2015. Species selectivity in different sized topless trawl Lee, J. designs: does size matter? Fish. Res. 172:243-249. Crossref

2017. Northeast groundfish fleet shrinks with high lease prices. National Fisherman, 7 August 2017. [Available from website.]

Madsen, N., V. Tschernij, K. Hansen, and P.-O. Larsson.

2006. Development and testing of a species-selective flatfish ottertrawl to reduce cod bycatches. Fish. Res. 78:298-308. Crossref 
Milliken, H. O., and J. T. DeAlteris.

2004. Evaluation of a large-mesh panel to reduce the flatfish bycatch in the small-mesh bottom trawls used in the New England silver hake fishery. North Am. J. Fish. Manage. 24:20-32. Crossref

NEFSC (Northeast Fisheries Science Center).

2015. Gulf of Maine Atlantic cod: 2015 assessment update report, 8 p. Northeast Fish. Sci. Cent., Natl. Mar. Fish. Serv., NOAA, Woods Hole, MA. [Available from website.]

Revill, A., G. Dunlin, and R. Holst.

2006. Selective properties of a cutaway trawl and several other commercial trawls used in the Farne Deeps North Sea Nephrops fishery. Fish. Res. 81:268-275. Crossref

Rose, C. S., J. R. Gauvin, and C. F. Hammond.

2010. Effective herding of flatfish by cables with minimal seafloor contact. Fish. Bull. 108:136-144.

Rothschild, B. J., E. F. Keiley, and Y. Jiao.

2014. Failure to eliminate overfishing and attain optimum yield in the New England groundfish fishery. ICES J. Mar. Sci. 71:226-233. Crossref

Sistiaga, M., B. Herrmann, E. Grimaldo, R. B. Larsen, and I. Tatone. 2015. Effect of lifting the sweeps on bottom trawling catch efficiency: a study based on the Northeast Arctic cod (Gadus morhua) trawl fishery. Fish. Res. 167:164-173. Crossref
Suuronen, P., and D. L. Erickson.

2010. Mortality of animals that escape fishing gears or are discarded after capture: approaches to reduce mortality. In Behavior of marine fishes: capture processes and conservation challenges (P. He, ed.), p. 265-293. Wiley-Blackwell, Ames, IA.

Thomsen, B.

1993. Selective flatfish trawling. ICES Mar. Sci. Symp. 196:161-164.

van Marlen, B.

1993. Research on improving the species selectivity of bottom trawls in the Netherlands. ICES Mar. Sci. Symp. 196:165-169.

Wileman, D. A., R. S. T. Ferro, R. Fonteyne, and R. B. Millar (eds.). 1996. Manual of methods of measuring the selectivity of towed fishing gears. ICES Coop. Res. Rep. 215, 102 p. [Available from website.]

Winger, P. D., S. Eayrs, and C. W. Glass.

2010. Fish behavior near bottom trawls. In Behavior of marine fishes: capture processes and conservation challenges (P. He, ed.), p. 65-103. Wiley-Blackwell, Ames, IA. 